Meta

Journal des traducteurs

Translators' Journal

\title{
Translation and Ideology: A Study of Lin Zexu's Translation Activities
}

\section{Shunyi Chen}

Volume 62, numéro 2, août 2017

URI : https://id.erudit.org/iderudit/1041026ar

DOI : https://doi.org/10.7202/1041026ar

Aller au sommaire du numéro

Éditeur(s)

Les Presses de l’Université de Montréal

ISSN

0026-0452 (imprimé)

1492-1421 (numérique)

Découvrir la revue

Citer cet article

Chen, S. (2017). Translation and Ideology: A Study of Lin Zexu's Translation Activities. Meta, 62(2), 313-332. https://doi.org/10.7202/1041026ar
Résumé de l'article

Cet article est une brève étude des activités de traduction de Lin Zexu, abordée d'un point de vue idéologique. Lin n'était pas traducteur, mais plutôt initiateur et mécène d'activités de traduction. Ses activités de traduction, qui avaient pour objectif de contribuer à sa campagne anti-opium et à la résistance contre l'invasion britannique, se basaient sur des journaux et des livres occidentaux. Les activités de traduction n'étaient pas bien vues par le gouvernement des Qing ; les traducteurs pouvaient même être perçus comme des traîtres. L'attitude de Lin face à la traduction était à l'opposé de celle du pouvoir en place qui estimait que les traductions étaient de peu d'utilité. Pour Lin, la traduction était un moyen de s'informer sur le monde extérieur et d'apprendre de lui. Le conflit idéologique opposant la cour des Qing et Lin aura finalement raison de ce dernier, poussé à l'exil par le gouvernement, ce qui mettra fin à ses activités de traduction. Cette étude de cas démontre que l'idéologie dominante, grâce aux appareils de l'État, tend à l'emporter sur les idéologies qui s’y opposent.
Ce document est protégé par la loi sur le droit d'auteur. L'utilisation des services d’Érudit (y compris la reproduction) est assujettie à sa politique d'utilisation que vous pouvez consulter en ligne.

https://apropos.erudit.org/fr/usagers/politique-dutilisation/ 


\title{
Translation and Ideology: A Study of Lin Zexu's Translation Activities
}

\author{
SH UNYI CHEN \\ Guangzhou University, Guangzhou, China \\ shunyi.chen@students.mq.edu.au
}

\begin{abstract}
RÉSUMÉ
Cet article est une brève étude des activités de traduction de Lin Zexu, abordée d'un point de vue idéologique. Lin n'était pas traducteur, mais plutôt initiateur et mécène d'activités de traduction. Ses activités de traduction, qui avaient pour objectif de contribuer à sa campagne anti-opium et à la résistance contre l'invasion britannique, se basaient sur des journaux et des livres occidentaux. Les activités de traduction n'étaient pas bien vues par le gouvernement des Qing; les traducteurs pouvaient même être perçus comme des traîtres. L'attitude de Lin face à la traduction était à l'opposé de celle du pouvoir en place qui estimait que les traductions étaient de peu d'utilité. Pour Lin, la traduction était un moyen de s'informer sur le monde extérieur et d'apprendre de lui. Le conflit idéologique opposant la cour des Qing et Lin aura finalement raison de ce dernier, poussé à l'exil par le gouvernement, ce qui mettra fin à ses activités de traduction. Cette étude de cas démontre que l'idéologie dominante, grâce aux appareils de l'État, tend à l'emporter sur les idéologies qui s'y opposent.
\end{abstract}

\section{ABSTRACT}

This paper describes a brief study of Lin Zexu's translation activities from the perspective of ideology. Lin was not a translator himself, but an initiator and patron of translations. $\mathrm{He}$ organised translation activities with sources from foreign newspapers and books to help his anti-opium campaign and resistance to British invasion. Translations from foreign sources were not welcomed by the Qing government and translators were even regarded as traitors. Lin, however, had a contrasting attitude towards translation. To Lin, translation was a way to learn about the outside world and to learn from it. The Qing government, on the other hand, held the view that translations of foreign documents were of little use. The difference between Lin's view and that of the Qing court can be seen as an ideological divergence between Lin and the government he served. This culminated in the expulsion of Lin from the government, his exile and the termination of his translation activities. This shows how a state instigated ideological position can predominate over an oppositional ideology - in this case to the detriment of the state.

\section{RESUMEN}

Este trabajo es un breve estudio de las actividades de traducción de Lin Zexu desde la perspectiva de la ideología. Lin no era traductor, sino un iniciador y mecenas de traducciones. Organizó actividades de traducción a partir de periódicos y libros extranjeros para ayudar a su campaña contra el opio y resistencia a la invasión británica. Las traducciones de fuentes extranjeras no fueron bien recibidas por el gobierno Qing y los traductores fueron incluso considerados como traidores. Lin tenía una visión de la traducción contraria a la del gobierno. Para Lin, la traducción era una manera de conocer el mundo exterior y aprender de él. El gobierno Qing, por otro lado, opinaba que las traducciones de documentos extranjeros eran de poca utilidad. La diferencia entre la visión de Lin y la de la corte de Qing radica en una divergencia ideológica entre Lin y el gobierno al que servía. Esto llevó a la expulsión de Lin del gobierno, su exilio y el fin de sus actividades 
de traducción. Este estudio demuestra cómo una posición ideológica promovida por el Estado puede predominar sobre una ideología de oposición, en este caso en detrimento del Estado.

\section{MOTS-CLÉS/KEYWORDS/PALABRAS CLAVE}

Lin Zexu, activités de traduction, guerre de l'opium, idéologie dominante, idéologie oppositionnelle

Lin Zexu, translation activities, opium war, dominant ideology, oppositional ideology

Lin Zexu, actividades de traducción, guerra del opio, ideología dominante, ideología de oposición

Lin Zexu (1785-1850) was an outstanding statesman and national hero during the Opium War period (1838-1840) (Yang 1981: 1). He was born in Houguan (now Fuzhou City), Fujian Province. In his official career, he served as Governor-General of Huguang (now the provinces of Hunan and Hubei), Governor-General of Shan'gan (now the provinces of Shanxi and Gansu) and Governor-General of Yungui (now the provinces of Yunnan and Guizhou) in the Qing government. In late 1838 Lin was appointed as the imperial plenipotentiary commissioner by Emperor Daoguang to tackle opium affairs in Guangdong (Chen Yuan 1979: 185). As a scholar-official in the Qing government, Lin differed from other court officials and the emperor in that he believed that knowledge about foreign countries was strategically important if China was to resist the incursion of foreign powers. In particular, during the Opium War period, Lin put himself at odds with the dominant ideology of the time and instigated a translation unit aimed at gaining information about the English which would assist China in resisting invasion.

Translation was a courageous endeavour during the Opium War period. This was primarily because feudal rulers had completely lost confidence in their power and were not willing to support close contact of Chinese subjects with the outside world. Prior to the emergence of modern China, large-scale translation activities referred to as "translation climaxes" by today's researchers (Chen Yuan 1979: 185) - were undertaken. On the eve of the Opium War, the government of the day would not allow translation activities and even regarded them as subversive.

While previously the issue of ideology was confined to discussions about politics, it has recently become an area of interest in academic discussions about translation. According to Jiang Huimin (2010), ideology is inseparable from translation. Some scholars even go so far as to argue that all translational actions are ideological and that the relationship between translation and ideology is an ideological one (Schäffner 2003: 23). Lydia H. Liu (1995: 26) remarked, “Translation is no longer a neutral event untouched by the contending interests of political and ideological struggles. Instead, it becomes the very site of such struggles."

Scholars define the term ideology differently. The definitions of ideology listed by Terry Eagleton (1991/2007: xxi) include: a body of ideas characteristic of a particular social group or class; ideas/false ideas which help to legitimate a dominant political power; and systematically distorted communication. André Lefevere described ideology as "the conceptual grid that consists of opinions and attitudes deemed acceptable in a certain society at a certain time, and through which readers and translators approach texts" (Bassnett and Lefevere 2001: 48). In a previous work, Lefevere 
claimed, "On every level of the translation process, it can be shown that, if linguistic considerations enter into conflict with considerations of an ideological and/or a poetological nature, the latter tend to win out" (Lefevere 1992: 39). Translation is a means of cultural exchange, behind which lie invisible ideological confrontations between different interest groups. It is an indisputable fact that ideology exerts considerable influence on translation. This influence can be seen in both the selection of source texts and in the strategies employed in the actual translation. This is true especially when a society is facing a major challenge.

This paper is a study of Lin Zexu's translation activities from the perspective of ideology. Specific focus is given to work initiated, funded and organised by Lin. The following aspects will be analysed: Lin's motivation for translation, his selection of source texts, steps or procedures he employed, and his translation strategies. All of these aspects reveal his ideology and are influenced by it. Lin was not capable of translating, as he didn't know any foreign language. As Lin's ideology was different to that of the Qing court and its Emperor, there was constant conflict between the two. This conflict ended in the disbandment of Lin's group of translators and ultimately to his exile.

\section{Dominant Ideology of the Qing Government}

The term ideology was coined by French theorists Cabanis, Destutt de Tracy, and colleagues as a theory or a science of ideas (O’Neal 1996: 227). In the work of Marx and Engels, ideology refers to social ideological forms representing the interests of the ruling class who legitimate and naturalise them (Marx 1995: 33). Eagleton (1994: 99) defined ideology as "the system of the ideas and representations which dominate the mind of a man or a social group." In a feudal society such as the one that existed in the Qing era, the ideology of the imperial rulers, was inevitably the ruling or dominant ideology. As Marx claimed, "The ideas of the ruling class are in every epoch the ruling ideas" (Marx and Engels 1965: 61).

The issue of ideology as it pertains to translation became prominent in academic discussions in the early 1990s. Lefevere (1992), drawing on Russian formalism, concluded that translation is rewriting after examining the role of ideology, patronage and poetics in translated literature. For him, patronage consisted of three closelyrelated components in order of importance: an ideological, an economic, and a status component. In Lefevere's understanding, ideology determines translation strategies and solutions to translation problems (Lefevere 1992: 51). Ideology is often enforced by patrons (people or institutions) and translators tend to have relatively little freedom in translating, especially when translating for a patron. If the translators' ideology is not in opposition to the patron's ideology and if the translations are not in conflict with target culture ideology, it is easier for the translations to be accepted in the target culture society.

Hatim and Mason (1997: 143) hold the view that ideology shapes discourse and discourse practices help to maintain, reinforce or challenge ideologies. As a form of discourse practice, translation is shaped by ideology and helps to maintain, reinforce or challenge ideologies. It involves a two-way dynamic process. All uses of language reflect a set of user assumptions which are closely bound up with attitudes, beliefs and value systems (Hatim and Mason 1997: 144). Hatim and Mason (1997: 147) hold 
that the translator has a filtering function, namely, to filter the text world of the source text through his/her own world-view/ideology. It is widely known that in many cases translators filter away contents or elements which are inconsistent with their ideology and the ideology imposed on them by their patron. This filtering is realised by various translation strategies and is indeed a process of ideological manipulation.

In Qing society, the landlord class owned the majority of land and controlled the means of material production. Whoever controlled the means of material production controlled the means of intellectual production. Translation, as a means of intellectual production, was in the hands of the ruling class, controlled by the ruling intellectual force. It is known that the Qing government adopted a closed-door policy in which international exchanges were not welcomed. During the period of the Qing government, translation was not a common occurrence. It was not allowed by the Emperor and was even banned by imperial officials. For instance, Qi Shan, a court official, commented, "Unlike Governor-General Lin, as an imperial official of the Celestial Empire, I do not probe into foreign affairs" (Wei 1976: 174-178). The view of translation aired here by Qi Shan also prevailed within the Qing court. It seemed that to Qi and his like, it was shameful to probe into foreign affairs and that an imperial official was not attending to his proper duties by doing so. Yu Qian, GovernorGeneral of Minzhe (now the provinces of Fujian and Zhejiang), once issued an order that books on foreign affairs be destroyed immediately."

Emperor Daoguang himself even insisted that Chinese people be cut off from foreigners, stating repeatedly that "there should be no association between Chinese subjects and barbarians (foreigners)." ${ }^{2}$ Further, translation was associated with treacherous collusion with foreign countries and translators were equated with traitors. As such, translators often risked execution. This official attitude to translation and foreign language skills in general, led to a serious lack of foreign language talents in modern China, especially translators and interpreters. The few who translated or interpreted a foreign language were referred to as “通事” (tong shi, “linguists”) and invariably received a low salary and were of low social status. All this meant China took a passive approach to diplomatic activities and military operations, and resulted in great economic and sovereign loss.

\section{Lin Zexu's Ideology as Oppositional Ideology}

In a society, there are various ideologies representing different interest groups. The ideology of the ruling class is usually the dominant ideology, whose status is often enforced by state repression. Other ideologies may either conform to or contradict the dominant ideology. The contradictory ideology is often referred to as oppositional ideology (McLaren 1991: 71). In the Qing court, Lin Zexu's ideology of translation was dramatically different to the ruling ideology. A weekly newspaper made the following comments on Lin: "While Lin acted totally contradictorily to the high authorities: he prepared several natives with most competence in translation" (Chinese History Society 1954: 412). Fortunately for Lin, the Emperor was not aware of his activities or else the results would have been disastrous. In a feudal society where the Emperor was the symbol of supreme authority, no one was allowed to contradict his views. To do so was to be suspected of deceiving the Emperor and the death penalty would apply. Lin was actually risking his life in organising translation activities. 
Lin assumed multiple roles in the translation activities. He was not only an initiator and a patron, but also a direct participant in various steps of the "translational chain." The roles Lin assumed in the translation activities were evident indicators of his oppositional ideology.

\subsection{Lin Zexu as Patron}

Patronage can be exerted by persons or by groups of persons, a religious body, a political party, a social class, a royal court, publishers, and the media (Lefevere 1992: 13). As previously mentioned, patronage is comprised of three elements: an ideological, an economic, and a status component. The ideological component acts as a constraint on the choice and development of both form and subject matter; the economic component sees to it that writers and rewriters are able to make a living; the status component implies integration into a certain support group and its lifestyle (Lefevere 1992: 16).

From 1839 to 1841, Lin organised a series of translation activities after his being appointed plenipotentiary imperial commissioner and before being expelled from the Qing court and forced into exile. He was actually a patron of translation. As is the main argument, ideology affects such aspects as selection of source texts, translation procedures, and translation strategies. The three components of patronage played their role in Lin's translation activities as his translators enjoyed high status and due support from him. Lin's translation activities were self-funded (not funded by the government) and conducted in secret. His translation activities were thus not known to ordinary people, or even the imperial court (Huang 2013). The activities were known to only a few imperial officials such as Guan Tianpei, Deng Tingzhen and Yi Liang. Lin's secret translation activities were based on the following two considerations: to avoid being involved in unnecessary political waters, and to protect his translation work from being disturbed (Huang 2013). Being secret and undisturbed, his translation work turned out to be fruitful.

\subsection{Lin Zexu as Participant in the Translation Activities}

In fact, Lin was not only a source of funds, but a participant in each step of the "translational chain." For instance, he was involved in data collection through various sources and channels by every possible means. He also helped to choose the texts to be translated (source texts). Furthermore, he polished the translations, particularly those to be presented to the Emperor which were usually in the guise of memorials. Lastly, he jotted down notes and comments between the lines to explain vague points, state his opinions on certain topics, or to point out mistakes.

Lin thus assumed multiple roles: initiator, patron, editor, compiler, reader, reviewer, and critic. The following paragraphs illustrate Lin's direct participation in the translation activities with examples. His roles and responsibilities are rather complicated and may even be considered a separate research topic. His patronage role is discussed here because his translation activities were initiated, funded and organised by himself rather than the government, and non-governmental activities led to opponents in the Qing court such as Qi Shan. 


\section{Lin Zexu's Translation Activities Affected by His Individual Ideology}

Lin's translation activities were influenced by his individual ideology. A comprehensive study of his translation activities will help demonstrate what his ideology was.

\subsection{Motivations of Lin Zexu's Translation Activities}

Lin Zexu's translation work took place at a special time in the past, specifically, the period of the Opium War. As we will see, his translations cannot be separated from their historical context or from his motivation as a patron.

Lin's motivation for translation was passive rather than active. Had he not been appointed imperial commissioner to combat the opium trade he would not have initiated the translation activities; nor would he have been allowed to do so. Lin's motivations for translation can be summarized as follows: first, to learn about foreign affairs in order to prepare countermeasures; second, to provide intelligence for the anti-opium campaign and the fight against British invasion; and third, to save the nation from subjugation and thus ensure its survival.

Motivation has different layers and stages. In terms of a common cause, there are different minor motivations or purposes, all of which serve the ultimate aim (Nord 1997: 28). Among Lin's motivations, to learn about foreign affairs in order to prepare countermeasures is especially apparent in his newspaper translation. He wrote in a memorial to the throne: "It is a crucial moment to guard against foreigners. We have to probe into foreign affairs from time to time to gain a clear picture as to what they are doing so as to work out precautions" (Chinese History Society 1954: 195). Lin's motivation to provide intelligence for the anti-opium campaign and the fight against British invasion was a direct response to the British opium trade and military threat. The motivation to save the nation from subjugation was the ultimate aim of his translation activities. As such, the first and second motivation elements both served the third.

Upon taking up office, Lin, like many other officials, made the following mistakes: 1) England had no ambition to invade China because of there being an internal struggle for the throne between Queen Victoria and her uncle; 2) China could control England through economic sanctions on the sale of tea and rhubarb; 3) The English military were inept at land battles, so accordingly, China could lure them into a land battle and thereby prevail. As Lin learned more and more from translations and foreign contacts, he came to understand that these assumptions about the English were false. He then came to realise that knowledge of the enemy was integral to victory. For Lin, translation and promulgation of the translated information about the enemy was a method of gaining this knowledge.

\subsection{Lin Zexu's Translators}

During Lin's lifetime, foreign language talents were rare in China and translators and interpreters were even rarer. There were a small number of linguists or compradors ${ }^{3}$ who knew a little English, but they were regarded as being of low social status and were very often mistreated as traitors (Chen Yuan 1979: 185). In turn, it was not easy for Lin to find suitable translators and to attract them he offered a monthly salary of more than 10 taels, equalling the monthly pay of a high-ranking court official (Shao and Lin 2002). Subsequently, Lin employed four permanent translators/inter- 
preters, and quite a few temporary ones. The following section briefly introduces the permanent translators/interpreters.

Yuan Dehui was a native of Sichuan Province. He was Roman Catholic by faith. He studied at a Roman Catholic school at Penang, and then at the Anglo-Chinese College, Malacca. Yuan had special language talents. He was familiar with Latin and had solid attainments in Chinese. He studied English at the Anglo-Chinese College for sixteen months and demonstrated a high degree of proficiency. At the end of 1829 Yuan became an interpreter at the Court of Colonial Affairs for the Imperial Government in Beijing. He was later employed as a translator by Governor Li Hongbing. Yuan became Commissioner Lin's translator and interpreter when Lin arrived in Guangzhou in early 1839 (Hunter 1885: 178, 215-216, 260).

Aman (in Guangdong dialect, 阿孟/亚孟), whose full name is unknown, ${ }^{4}$ was born to a Chinese father and a Bengali mother. He was a disciple of a Christian missionary, Joshua Marshman, in Serampore, Bengal (Fay 1997: 160). Aman arrived in Guangzhou around 1830 and was recruited by Lin as an interpreter/translator in early 1839 (Zheng 2004).

Alum (in Guangdong dialect, 阿林/亚林), whose real name was Lin Shi (林适), studied in the US in his early years: first in Connecticut and then in Pennsylvania (Britton 1933: 31-32). He arrived in Guangzhou in 1825 and was recruited by Lin as an interpreter/translator in 1839 (Smith 1985: 56-57).

Liang Jinde, son of Liang Fa - the first priest of Protestantism in China - was born in Gaoming, Guangdong Province. He was trained by Elijah Coleman Bridgman to do Bible translation. ${ }^{5}$ Liang was recommended to Lin by his father Liang Fa, who later assisted his son with his translation work. Liang translated British writer Hugh Murray's Cyclopaedia of Geography into Chinese. ${ }^{6}$ Its Chinese version bore the name “四洲志” (Si Zhou Zhi, “Four Continents”). Liang was regarded as the most competent translator among the four.

\subsection{Lin Zexu's Translation Activities}

Lin Zexu's translation activities covered newspapers, books and diplomatic correspondence, with the book translations including anti-opium information, scientific materials, and legal matters.

\subsubsection{Lin Zexu's Newspaper Translation}

Lin Zexu's translations of newspapers were mainly of Canton Press. He named the translated newspaper Macau News, but this was not the name of an official newspaper. It was so named because the source newspapers were published at Macau at that time. Lin's translation of newspapers commenced in March 1839 and ended in late October, 1840. The translations were conducted according to the following six steps. First, Lin sent his men to Macau to purchase relevant newspapers. Second, Lin worked with his translators to determine which texts were to be translated. Third, Lin ordered his translators to start translating the texts. Fourth, Lin proofread some of the translations and polished the paragraphs or added critical notes. Fifth, Lin ordered his translators to bind the translations chronologically into volumes. Sixth, Lin asked his men to deliver the bound volumes to open-minded court officials for their references. Put simply, the steps are: 1) raw material purchase; 2) selection of source texts; 
3) translation; 4) proofreading and polishing; 5) editing and compiling; and 6) release of target texts. This was a scientific process even by today's perspectives.

\subsubsection{Newspaper Sources}

There is no consensus regarding the sources of Lin's newspaper translations. It is generally thought that Lin's source newspapers were mainly Chinese Repository, Canton Press, and Canton Register, but scholars differ on this point. For instance, Qiandui Wu and Kuangshi Chen (1980) suggest Lin's source newspapers were mainly Canton Press, Canton Register, and Singapore Free Press, with sporadic sources of newspapers published in Bombay, India. Furthermore, Shenglin Chen (1990) asserts Lin used other minor newspaper sources published in such locations as Bengal, London, Calcutta, and Sydney whose names are unknown.

\subsubsection{Translation Strategies}

Translation strategies can be divided into macro-strategies and micro-techniques. As for the macro-strategies, evident in Lin's newspaper translation, adaptation or editing, abridging, abstracting, and restructuring were employed. As for microtechniques, there is evidence of literal translation, transliteration, note-adding, etc.

The newspaper articles were adapted, edited and bound together in a chronological order. To facilitate the reading experience, Lin classified the translated newspaper articles into several categories based on theme and then compiled them into an anthology. This anthology had five separate sections dealing with five different themes. The different subtitles were: On China, On Tea, On Anti-Opium Campaign, On Arms Use, and On Affairs of Foreign Countries (Chen Shenglin 1990). Abridging, abstracting and restructuring were quite common in Lin's newspaper translation as they are in today's news editing. Lin selected only contents of immediate relevance, and sometimes restructured the source texts to achieve this purpose.

Literal translation was a frequently-used technique in Lin's newspaper translation as it directly conveyed the original information. One of the striking features of the translations is its faithfulness to the source texts (Zheng 2004). Lin's newspaper translation was to help him gain access to useful information for his anti-opium campaign and for the fight against British invasion. Literal translation takes the least amount of time to perform and remains closest to the original meaning and information. If done well, literal translation can be recovered via back-translation.

In rendering proper names of places, persons, and institutions, transliteration was frequently employed by Lin's translators. For example, “律好司” (lv hao si, “the House of Lords”), “甘文好司” (gan wen hao si, “the House of Commons”), and “巴厘满” (ba li man, “Parliament”), to list just a few. What's more, Lin's translators added “口” (kou, "mouth") to the left side of all place names, even though these characters did not exist in the Chinese language. For example, “嘶噶兰” (si ge lan, “Scotland”), “嗳伦” (ai lun, “Ireland”), and “孟啊啦” (meng a la, “Bengal”). This is actually a scientific process for transliteration and touches upon the essence of the technique, that is, how we pronounce the words. It is a transcription of the sounds we make with our mouths.

Notes in the translated news articles fall into two categories: explanatory paragraphs by translators, and critical comments by Lin himself. As per the topic of this paper, four examples of the second category are presented below: 
1) An article on China's prohibition of religions on 16 November, 1839 reported that China banned Catholicism and Christianity. The following note was appended to this article: "The Jesus religion brought by Matteo Ricci upon his first arrival was Catholicism, while the Jesus religion passed by Ferdinand Verbiest upon his first arrival was Christianity. The two were quite different" (Chinese History Society 1954: 403). This is once again a mistake as both Matteo Ricci and Ferdinand Verbiest spread Catholicism in China. Among Lin's translators, Yuan Dehui and Liang Jinde were both graduates from church schools and believers in religion. As such, they could not have made such a mistake. It is most probable that Lin added this note as a comment.

2) On 3 December, 1839 the newspaper published an article on opium monopoly in India. It reported the tax contracting triggered bootlegging and it was hard to levy land duty. A note followed, "Just like China's salt works is fixed at a certain location to avoid bootlegging" (Chinese History Society 1954: 440). This comment links the opium tax to China's salt tax. Lin used to be Chief Superintendent of the Salt Department of Zhejiang Province. He knew how to combat salt smuggling and bootlegging and thus this note was most probably added by him.

3) A comparison was made between tax revenue and the number of troops among China, Russia, Britain and France on the newspaper of 16 May, 1840. It was followed by a short line: “The data about China's tax revenue were all incorrect. What were they based on?" (Chinese History Society 1954: 473) Lin, in the position of Imperial High Commissioner, naturally knew China's tax revenue well, while his translators were not in a position to have access to all relevant data.

4) On 5 September, 1840 the newspaper published a report on a new book which included most government notices. It also included Lin's opium-banning notice, opium turnover notice, and his letter to the Queen of England. There was a short line beside the report, "This book is to be sought in Macau" (Chinese History Society 1954: 512). It is known that Lin sought information from various channels and by every means. He was very interested in accessing useful information and sent people to many locations to search for newspapers and books. Thus we have every reason to believe that this short note was written by Lin.

\subsubsection{Significance of Newspaper Translation}

Lin's translated newspapers had a very small readership (Tang 2007). They were mainly for his references to the fight against the illegal opium trade and to save the nation from subjugation and ensure its survival. His readers were open-minded government officials such as Guan Tianpei, Deng Tingzhen and Yi Liang, to whom Lin often sent translations. When Lin felt it necessary to inform the Emperor of something in the translations he may have polished the translations and sent them to him in the guise of memorials. Thanks to Lin's efforts, translating foreign newspapers as references was gradually accepted by the Imperial Court.

In the Second Opium War (1856-1860), Self-Strengthening Movement officials such as Gui Liang gave frequent mention to the translated newspapers. In addition, during the reign of Guangxu half a century later, reading newspapers became a basic requirement for court officials. Lin opened a window to the outside world through which not only he and his colleagues peered, but also ordinary Chinese people. Newspaper translation helped Lin to expose false assumptions and move him from ignorance to rich knowledge. Furthermore, Lin's newspaper translation helped him keep contact with the modern world and understand the features and regularities of foreign invaders. He came to realise that foreign colonialists were forcing China into 
subordination. He also came to know the true colours of the colonialists as a result of translating the newspaper articles. Bearing these benefits in mind, Lin could work out his work plans accordingly.

\subsubsection{Lin Zexu's Book Translation}

Lin Zexu's book translation activities covered a wide range of topics including history, geography, trade, law, and technology. The books were also obtained from various sources.

\subsubsection{Collection of Source Texts}

Lin utilised several channels in the process of data collection. These channels included inquiries and interrogations, donations, and purchases from foreigners. American missionary E. C. Bingham mentioned how Lin collected data via inquiries:

During his [Lin's] stay at Chuenpee [Humen], his secretary and aides-de-camp, with other intelligent men, were employed making inquiries, and noting down the answers on every branch of policy and trade, and especially as to what might be the consequence of his present measure; and what compensation would be most agreeable to the owners of the opium.... These observations were daily presented to the commissioner, who had formed a thick volume by the time he returned to Canton. (Bingham 1843: 81-82)

In addition to making inquiries, Lin also availed himself of every opportunity to interrogate captives in order to seek for extra information.

As for donations, Lin retrieved all of the books in the reference room of Spanish brig Bilbaino. Information regarding the contents of the books and the amount he retrieved, however, is not available. Lin retrieved a slew of books from Bridgman in a meeting with him, including A Dictionary of the Chinese Language compiled by Protestant missionary Robert Morrison. Lin accepted donations from Dr. Parker ${ }^{8}$ that included a series of maps, geographic books, and a globe. Lin also bought books from foreigners as evidenced in the following statement printed in Macau News, “There are several foreigners, who are willing to widen Chinese people's knowledge by selling good British books to China, who had the books translated generally by employed translators" (Chinese History Society 1954: 412).

Selection of source texts reveals ideology and serves ideology. Lin's choice of source texts was not an impulsive act, but a deliberate one. Ideology of the target culture and ideology of the patron both determined which texts were to be translated and which were not. In choosing texts to be translated, Lin's personal ideology favoured pragmatism which provided an ideological basis for his translation activities. Lin's ideology centred on controlling the enemy in choosing source texts. The topics touched upon practical matters like geography, law, navigation, and gunnery.

\subsubsection{Lin Zexu's Anti-Opium Translation}

According to Dr. Hill, surgeon of British bark Sunda, ${ }^{9}$ Lin showed the survivors of the ship two English books with Chinese translations of several passages (Waley 1958: 89). One was Algernon S. Thelwall's The Iniquities of the Opium Trade with China, and the other was John Francis Davis' The Chinese: A General Description of the Empire of China and Its Inhabitants. The former was published in London in 1839, which "makes an eloquent appeal for the suppression of opium production in India." 
The latter was published in London in 1836 and shows "great appreciation of Chinese literature and drama, and of Chinese institutions and customs in general" (Waley 1958: 89). The title The Iniquities of the Opium Trade with China was rendered to “对华鸦片贸易罪过论” (dui hua ya pian mao yi zui guo lun, “The Sins of Opium Trade to China") and the title The Chinese: A General Description of the Empire of China and Its Inhabitants was rendered to “华事夷言” (hua shi yi yan, “Barbarians' Words on Chinese Affairs"). The rendering of The Chinese: A General Description of the Empire of China and Its Inhabitants into “华事夷言” is a shift of perspective from third-person objective description to first-person subjective representation. This reveals Lin's and his translators' ideology of self-centredness and superiority over foreign countries.

Thelwall's book was written directly about the opium trade, whereas Davis' book was about what an English merchant saw and heard in China. Thelwall's book helped Lin to know that in England there were people who strongly opposed the opium trade. Thelwall attacked the opium trade on both religious and ethical grounds. Thelwall was a representative of the cotton cloth capitalists who wanted to sell their cotton cloth to China. However, the opium trade dominated Britain's trade in China and the cotton cloth trade was subsequently enveloped in a bear market. The cotton cloth capitalists were aware of the impact of the opium trade and launched a fierce attack against it, hence the book. Notably, all of this was unknown to Lin at the time. What he did know was that there were opponents of the opium trade even in England. In turn, he realised he could use this conflict to "attack barbarians with barbarians and control barbarians by barbarians" (Wei 1852). At this time, Lin also came to understand that legal trade and illegal smuggling should be differentiated, and all legal businesses of foreign merchants should be supported and protected. To Lin, Davis' book was of great value in that it provided a detailed account of the extent of the opium smuggling and this helped him broaden his knowledge of the practice.

\subsubsection{Lin Zexu's Scientific Translation}

Lin's scientific translations centred on the purpose of controlling the enemy. For example, to help the Qing government in its political and military confrontations with foreign countries, Lin initiated on December, 1839 the translation of Cyclopaedia of Geography by Scottish geographer Hugh Murray. The translation was completed by Liang Jinde and bore the name “四洲志” (Si Zhou Zhi, “Four Continents”).

Si Zhou Zhi is a world geographic work. It was named by Lin following Buddhist scriptures (Chen Xiaoming 1998), according to which the earth was divided into four continents. ${ }^{10}$ The translation of the book title represents an ideological position. Cyclopaedia of Geography was a mere objective description, while “四洲志” (Si Zhou Zhi, "Four Continents") was a Buddhist discourse. Thus, it was a transfer from objective description to subjective representation. The translation also revealed the self-centred focus of Lin's and his translators' ideology as Buddhism was a traditional Chinese religion and one of China's ideological foundations. Cyclopaedia of Geography covers more than 30 countries in the world, but Lin chose only those countries which posed great threat to China. The original work covered more than 1,500 pages, and the final product was reduced to only 49 pages of 114,000 words (Xiao 1999). Accounts of the US and the UK comprised four-fifths of the total volume. 
Cyclopaedia of Geography begins with a focus on Europe and then moves on to other continents. Lin changed this order, however, and transitioned the focus from near to far, and from east to west with China at the centre. He omitted accounts of China and started at Vietnam, Thailand, and Burma to the south, on to India and South Western Asian countries to the southwest, then to Africa and Europe, before ending at America (the American Continent) (Luo 2002: 6). This order shows Lin's China-centred awareness, which was no different to that of other imperial officials. It is a false consciousness from today's perspective, but it was very popular and firm in the minds of Chinese people in that historic period.

Lin also corrected some of the errors in the original work and commented by adding notes between the lines. For example, the original author divided the Chinese Empire into three sections: China, Tibet, and Eastern Tartary, and indicated the last two sections were foreign dominions of China (Xiao 1999). This is in fact the fallacy of "three Chinas" (Chen Hua 1993). Lin added notes to correct this error and removed this part in the translation. To help readers understand the book Lin also added copious notes explaining some of the difficult points or proper names. For example, Lin added a note to Nile River, the longest river in Egypt, explaining "It is Nile River in Kunyutushuo (Illustrated Explanation of the Entire World), with a length of 7,800 $l i^{11}$ and seven channels" (Xiao 1999). Regarding the purpose to identify strategies for resisting the British invasion, Lin paid special attention to the sources of military power in various countries. He was very interested in Vietnam, a neighbour of China to the south, which learned how to improve its military strength from foreign countries. He commented in the notes:

Out of gratitude for European assistance and admiration for its Warcraft, Emperor Guangzhong modelled on its warships and firearms. Vietnam now has 300 bomb vessels and 1 naval vessel and has no matches in other Asian countries. Thus, it combines Vietnam, Tokyo and Cambodia into one ruling. (Chen Hua 1993: 73-82)

Lin also appreciated Russian Emperor Peter the Great, who pushed Russia to prosperity via reform. He commented in the notes section:

Peter the Great was smart and remarkable. He left the capital and paid private visits to shipyards and firearms plants in Amsterdam in disguise to learn its craft and returned to pass it on to his subjects, who built the craft firearms and warships which were even better than Holland" (Xiao 1999).

Lin's pragmatic ideology was everywhere to be seen. Si Zhou Zhi covered the majority of the countries in the world and pushed Chinese people towards a big leap forward in knowing the outside world and erasing previous misconceptions such as "China is the center of the world," "China is the most prosperous country in the world," and "people in foreign countries are barbarians" (Chinese History Society 1954: 365).

\subsubsection{Lin Zexu's Legal Translation}

Lin Zexu's legal translation was of Le Droit des Gens authored by Swiss legal expert Emmerich De Vattel. The book was first published in 1758, and then translated into English bearing the name The Law of Nations, or Principles of the Law of Nature: Applied to the Conduct and Affairs of Nations and Sovereigns. The translation was so popular that new editions of translations were printed one after another in both the 
UK and the US. The first English translation appeared in 1759, one year after the publishing of the original work. New editions subsequently appeared in quick succession. It is believed Lin's translators, Dr. Parker and Yuan Dehui used Joseph Chitty's 1783 English translated version as the source text for translation into Chinese in 1839 (Wang 1985).

The Chinese version bore the name “各国律例” (ge guo lv li, “law of nations”). The original work was abridged to a great extent and only articles concerning the harbour blockade, ship embargo, treatment of expatriates, etc., were left in the translated version. As a result, it was much thinner than the source text. The articles were of urgent relevance to controlling enemies. According to Huang and Wang (2014), "jump translation" was a very common form of translation. For example, in Chapter 39, Article 9 was followed by Article 172, thus 163 articles were "jumped over" (omitted) between them. Lin's translations were seldom full or complete, with partial or abridged translations appearing to a much greater extent. Only useful information or materials of great value or urgent need were translated. Translation to Lin was a tool or means, not an end. Indeed, he did not complete translations for translation's sake, but for practical purposes.

It is generally regarded that Yuan's translation version is better than Parker's for two reasons. First, Yuan translated after Parker with reference to Parker's version. Second, translating from English into Chinese is relatively easier for a Chinese native speaker who feels more at ease in using Chinese expressions. Furthermore, Yuan's translation is more concise, precise and idiomatic in expression.

To help Chinese readers to understand and accept the book, Yuan tried every means possible. He changed and omitted chapters and complex arguments to reflect the situation in China. He omitted chapters and concepts such as "general will" and "state will" unsuited for China at that time. In fact, he shifted the concepts of "general will" and "social order" to the perspective of interpersonal relationships rooted in traditional Chinese ethics. Yuan's starting point was traditional Chinese ethics and morality, and Chinese social order, and he viewed every concept in international law from this starting point.

Lin, as an open-minded feudal scholar-official, did not challenge this confinement. All the translation activities he organised were for the purpose of maintaining the feudal order and protecting the interests of the landlord class. As an employee of Lin's, Yuan had to obey Lin's order and act in accordance with his will. In turn, Yuan shifted the concept of "law" as objective existence to an object of emotions, something quite subjective. He also situated international law within the Chinese tradition, which is naturally incompatible with Vattel's original intention.

In terms of translation strategies, Parker employed foreignization, while Yuan employed domestication. Parker attempted to re-establish an understanding of international law based on Christian ethics and moral order; whereas Yuan's diction and argumentation were deeply rooted in Confucian ethics. Parker's rendering was literal; whereas Yuan's was free. International law should represent modern ideas in modern language, but Yuan interpreted them in traditional language. Dr. Parker's and Yuan's dictions as shown in the following examples formed a sharp contrast: 
TABLE 1

Dr. Parker's and Yuan Dehui's dictions in translating The Law of Nations

\begin{tabular}{|c|c|c|}
\hline Source Text & Parker's Translation & Yuan'sTranslation \\
\hline law of nature & $\begin{array}{l}\text { 性理之常(xing li zhi chang, "the } \\
\text { law of nature"12) }\end{array}$ & $\begin{array}{l}\text { 所怀之忿(suo huai zhi fen, } \\
\text { "indignation harboured") }\end{array}$ \\
\hline fanatics & (untranslated) & $\begin{array}{l}\text { 迂儒 (yu ru, "pedantic Confucian } \\
\text { scholar") }\end{array}$ \\
\hline right & (untranslated) & 道理 (dao li, “reason”) \\
\hline reason & 情 (qing, “circumstance”) & 道理 (dao li, “reason”) \\
\hline $\begin{array}{l}\text { rule of justice, equity, } \\
\text { and humanity }\end{array}$ & $\begin{array}{l}\text { 人心, 天理 (ren xin tian li, “man's } \\
\text { heart, and God's justice”) }\end{array}$ & $\begin{array}{l}\text { 仁义之律法 (ren yi zhi fa lv, "law of } \\
\text { benevolence and righteousness") }\end{array}$ \\
\hline complain & 委屈 (wei qu, “injustice”) & 怨恨 (yuan hen, “resentment”) \\
\hline office of humanity & $\begin{array}{l}\text { 仁情 (ren qing, "benevolent } \\
\text { humanity") }\end{array}$ & 本分 (ben fen, “one’s duty”) \\
\hline
\end{tabular}

\subsubsection{Lin Zexu's Diplomatic Correspondence Translation}

There was no Ministry of Foreign Affairs within the Qing government. The imperial court treated foreign affairs as internal affairs to be managed by local officials. Due to China's closed-door policy there was little diplomacy shown to other nations, at least diplomacy in the strict sense. The relationship between the Chinese empire and foreign countries, especially neighbouring countries, was a tributary one, that is, they had to pay tributes to China to gain favour from the Imperial Emperor and to seek protection from him (Chang 1964: 2). This situation changed dramatically when England increased its opium sales in China and called for wider markets for opium and other products. England and other European countries were not satisfied with the tributary system and required equal diplomatic relations with China.

When Lin arrived at Guangdong as Imperial Commissioner he was the sole diplomat in the province and the sole channel for foreign exchanges. He shouldered the diplomatic responsibilities associated with representing Emperor Daoguang. His diplomatic identity was imbedded in his translation activities, especially the translations of diplomatic correspondence such as his letter to the Queen of England. The letter to the Queen of England was written by Lin Zexu, Deng Tingzhen and Yi Liang in Chinese, dated June, 1839. It was translated into English first by his translator Yuan Dehui and then back into Chinese by the American merchant Hunter. Lin asked Hunter to translate Yuan's English translation back into Chinese to determine whether or not it was equivalent to the original Chinese version. Lin then asked Dr. Parker to conduct another translation from the original into English to determine whether or not Yuan's translation was correct. When Lin had a chance to meet Dr. Hill he asked him to proofread the two translations made by Yuan and Parker respectively.

The letter was rather long, with a detailed account of the evil effects of the opium trade, and with a plea the Queen of England to bring it to an end. The original letter in Chinese was full of superfluous and boastful dictions, which were still traceable after Dr. Hill's polishing. The letter opens with the following lines: ${ }^{13}$

洪惟我大皇帝抚绥中外, 一视同仁, 利则与天下公之, 害则为天下去之, 盖以天地之心 为心也。 
Magnificently our great Emperor soothes and pacifies China and the foreign countries, regarding all with the same kindness. If there is profit, then he shares it with the peoples of the world; if there is harm, then he removes it on behalf of the world. This is because he takes the mind of heaven and earth as his mind. (Yuan Dehui's version)

It is only our high and mighty emperor, who alike supports and cherishes those of the Inner Land, and those from beyond the seas - who looks upon all mankind with equal benevolence - who, if a source of profit exists anywhere, diffuses it over the whole world - who, if the tree of evil takes root anywhere, plucks it up for the benefit of all nations: - who, in a word, hath implanted in his breast that heart (by which beneficent nature herself) governs the heavens and the earth!(Parker's version)

The letter ends with the following lines: ${ }^{14}$

我天朝君临万国, 尽有不测神威, 然不忍不教而诛。

Our Celestial Dynasty rules over and supervises the myriad states, and surely possesses unfathomable spiritual dignity. Yet the Emperor cannot bear to execute people without having first tried to reform them by instruction. (Yuan Dehui's version)

Our celestial empire rules over ten thousand kingdoms! Most surely do we possess a measure of godlike majesty which ye cannot fathom! Still we cannot bear to slay or exterminate without previous warning. (Parker's version)

Yuan's translation is literal in that it rigidly adheres to the Chinese original. In contrast, Parker's translation is free in that it does not follow the syntax of the original, and thus had a higher degree of acceptability. Yuan's capitalisation of "Our Celestial Dynasty" denotes the supreme status of the Chinese empire which was to rule over the world under heaven. Surprisingly, both Yuan and Parker, out of different considerations, used the same terms "heaven" and “earth” for “天” (tian) and “ 地” (di) respectively.

Throughout the entire letter Yuan used the word “barbarian” for “夷” ( $y i$ ) 16 times, while Parker consistently used "foreign/foreigner." The former is a derogatory term while the latter is a neutral one. In traditional Chinese, “夷” was used to refer to foreign people and countries to show Chinese people's contempt for them. To call foreigners "barbarians" was quite impolite, thus to render “夷” into "barbarian" though a literal and correct translation - was inappropriate. Why did Yuan translate “夷” into "barbarian"? Did he do it consciously or unconsciously? These questions are hard to answer today because there is no evidence available to support either of the assumptions. A possible answer is that Yuan did it purposely on behalf of the Qing government to show the Qing government's hatred for opium smugglers. It was a true revelation of the Qing government's ideology and also Lin's ideology. In Yuan's version, there were numerous words used to indicate the superiority of the Qing government over foreign countries, especially England. In contrast, Parker's equivalents for these words are somewhat neutral in tone, as can be seen in Table 2: 
TABLE 2

Yuan Dehui and Peter Parker's dictions in translating Lin's Letter to the Queen of England

\begin{tabular}{|l|l|l|}
\hline Source Text & Yuan's Translation & Parker's Translation \\
\hline $\begin{array}{l}\text { 恭顺 (gong shun, } \\
\text { "respectfulness and } \\
\text { submissiveness) }\end{array}$ & politeness and submissiveness & respectful and obedient \\
\hline 震怒 (zhen nu, “be enraged”) & in a towering rage & quivered with indignation \\
\hline $\begin{array}{l}\text { 懔遵 (bing zun, “obey with } \\
\text { awe”) }\end{array}$ & be absolutely obeyed with awe & $\begin{array}{l}\text { be obeyed with fear and } \\
\text { trembling }\end{array}$ \\
\hline 神 (shen, “spirit”) & spirits & gods \\
\hline $\begin{array}{l}\text { 格外天恩 (ge wai tian en, } \\
\text { “Heaven's special favor”) }\end{array}$ & extraordinary Celestial grace & extraordinary goodness \\
\hline
\end{tabular}

The contrasting foreignization and domestication strategies employed by Yuan and Parker respectively are also evident in other parts of the translations. For example, “里” ( $l i$ ) is a measurement in Chinese. Yuan transliterated it into “li," while Parker domesticated it into "mile." Unfortunately, this letter was declined by the British Foreign Office and it was never known to the Queen.

\section{Conflict between Dominant Ideology and Lin's Individual Ideology}

Unfortunately, Lin was held responsible for his inability to resist focusing on the British invasion in the Opium War and his suspected collusion with the Queen of England. As a result, he was exiled by the Emperor and his translation team was dismissed, thus terminating his translation activities. The ideological conflict between the Qing court and Lin resulted in the failure of the latter. In Chinese history, conflicts between dominant ideologies and individual ideologies typically result in a victory for the former (Gao 1994). For this reason, "wise" people, like Qi Shan, would keep their individual ideology hidden and adapted it to the dominant ideology to avoid falling into disfavour with the rulers.

In Lin's case, although his individual ideology was defeated by the dominant ideology, both were in turn defeated by the ideology of foreign powers. Seen from the perspective of translation, China's defeat in the Opium War was not only a military failure, but also an ideological one. Should the Qing court have paid due attention to learning from the outside world via translation, and should it have attached sufficient importance to translation activities, Chinese history during the Opium War could have taken a different course. Hence, the importance of translation in specific historical events and historical periods can never be exaggerated.

Lin, as one of the few officials in the Qing government who viewed knowledge of the enemy and its environment as a strategic advantage, remained in ideological isolation. Under the internal and external pressures of the Qing government and British imperialism respectively, Lin could not remain inactive and ended up being deposed from his position and exiled to Xinjiang. He failed in his battle, an ideological battle, and became a victim of it. His ideology was later proved to be correct. For example, in the Self-Strengthening Movement (1860s-1890s) that followed, translation was used as a weapon to strengthen the country and played its due role in achieving its goals, which were self-strengthening and prosperity. 
Lin spared no efforts in mediating between the dominant ideology and his individual ideology, but failed to achieve a compromise between the two. He could hardly agree to the former as he was one of the few open-minded people in the Qing court at the time. The ruling class all took a contemptuous attitude toward translation activities and translators, and very often equated translators with traitors. Traitors, according to Arthur Waley, are "Chinese who entered the service of foreigners, learnt foreign languages, corresponded with foreigners or made friends with them in any way" (1958: 222). Judged from this logic, both Lin and Lin's translators were "traitors" because Lin corresponded with foreigners and his translators studied English for a relatively long time. However, their self-centred and self-sufficing ideology was exclusive of anything foreign since they regarded China as the centre of the universe and all other countries as inferior and affiliated to China. To them, there was no such concept as foreign relations. Like other Qing officials, Lin had to promote the almightiness of the great imperial empire, protect its face, and gain favour from the Emperor. If there was an ideological conflict between the dominant ideology and Lin's individual ideology, the latter had to give way to the former.

It has to be pointed out that the ideology of Lin's translators' conformed with Lin's ideology primarily because they were employed and paid by Lin. A satisfactory salary arouses in employees a sense of self-pride and directly leads to loyalty to the employer. Lin's translators were absolutely loyal to Lin morally, ethically and ideologically. In fact, Lin was very particular in selecting translators and censoring their work in order to maintain their ideological loyalty. For example, Lin would very often ask two persons to translate the same text simultaneously, ask another person to back-translate, or consult another person for his opinion to check the validity of the translated work.

During his post as Commissioner, Lin organised a series of translation activities to help him cope with the circumstances at home and abroad. His translations provided valuable references for his anti-opium campaign and resistance to British invasion. His translation activities also had far-reaching impacts both within China and outside China. “海国图志” (hai guo tu zhi, “An Illustrated Gazetteer of the Maritime Countries"), compiled by Wei Yuan based on Lin's translations from English, was the first comprehensive and systematic book on world history and geography in modern China. Furthermore, part of this work was later translated back into English by Edward Harper Parker, an English barrister and sinologist. Parker's book bore the name Chinese Account of the Opium War. ${ }^{15}$

However, Lin's translated works were mostly for internal use. The translations were available to a very small readership such as open-minded court officials like Guan Tianpei, Yi Liang and Deng Tingzhen, as well as Emperor Daoguang. The translations were not known to the masses outside the court and they did not ignite the ideas and thoughts of others. Thus, their influence in China at the time was minor. While Lin and the Qing government held different ideological views regarding translation and the dissemination of information about the enemy, they held a common ideology relating to feudalism and property rights. It was only in their methods of protecting this supervening ideology that they differed and this difference was the cause of Lin's demise within the court. 


\section{ACKNOWLEDGEMENTS}

First, I would like to express my gratitude to the China Scholarship Council (CSC) and International Macquarie University Research Excellence Scholarships (iMQRES) for their funding and support. Second, I am indebted to Associate Professor Ilija Casule at Macquarie University and Professor Xiao Ma at Wuhan University for their constructive suggestions and close proofreading of the previous drafts before the final version. Whatever merits the paper happens to own should be attributed to the above-mentioned, while the errors and oversights remain my own.

\section{NOTES}

1. Yu, Qian裕谦 (1841): 裕忠节公遗书 [Posthumous Papers of Yu Qian]. Vol. 20.

2. LI, Zongdong 李宗侗(1930): 史料旬刊 [Historical Periodical]. 9:308.

3. Compradors are Chinese agents employed by foreign establishments in China to take charge of their Chinese employees. As intermediaries, they knew some basic English and usually assumed the role of translators or interpreters in business affairs.

4. Aman (阿孟/亚孟) is a nickname. His last name is supposed to be “孟” (meng) or there is definitely “孟” in his full name. According to the local custom in Guangdong, one is usually called in this way: Ah- plus any character in his/her full name. For example, Lin Shi is called either Ah-lin or Ah-shi, and Liang Fa is called Ah-fa.

5. The American Board of Commissioners for Foreign Missions (1840): Records of the American Board of Commissioners for Foreign Missions. I(30):16.3.8.

6. The Morrison Education Society (1841): The Third Annual Report of the Morrison Education Society, dated 29 September, 1841.Macau: S. Wells Williams.

7. Bridgman, Elijah Coleman (1839): Crisis in the Opium Traffic. The Chinese Repository.8:77.

8. Dr. Parker (1804-1888) was an American physician and missionary in China in the Qing Dynasty. He was the first Protestant medical missionary to China. He travelled to Canton in February, 1834 and opened the Guangzhou Boji Hospital in 1835. Apart from being an ophthalmologic expert, he was also a "temporary" translator employed by Lin Zexu.

9. The British bark Sunda was wrecked on 12 October, 1839 near the island of Hainan. The survivors from the wreck were kindly treated and interviewed by Lin Zexu at Canton.

10. The four continents are Zhanbu (South), Shengshen (East), Niuhe (West), and Julu (North).

11. $\quad l i$ is a Chinese measurement. One $l i$ equals 0.5 kilometre.

12. All translations in brackets are our translation.

13. Bridgman, Elijah Coleman (1839): Reports of the Medical Missionary Society. The Chinese repository.8:635

14. Bridgman, Elijah Coleman (1839): Reports of the Medical Missionary Society. The Chinese repository.8:636.

15. PARKer, Edward Harper (1888): Chinese Account of the Opium War. Shanghai: Kelly \& Walsh.

\section{REFERENCES}

Bassnett, Susan and Lefevere, Andrew (2001): Constructing Cultures - Essays on Literary Translation. Shanghai: Shanghai Foreign Language Education Press.

Bingham, John Elliot (1843): Narrative of the Expedition to China, from the Commencement of the War to Its Termination in 1842. Vol. 2. London: Henry Colburn Publisher.

Britton, Roswell Sessoms (1933): The Chinese Periodical Press, 1800-1912. Shanghai: Kelly \& Walsh.

Chang, Hsin-pao (1964): Commissioner Lin and the Opium War. Cambridge \& Massachusetts: Harvard University Press.

CHEN, Hua 陈华 (1993): 有关 《四洲志》的若干问题 [Several issues on Si Zhou Zhi]. Journal of Jinan University. 15(3):73-82.

CHEN, Shenglin 陈胜粦 (1990): 《澳门新闻纸》的翻译与林则徐走向“近代”的开端 [Aomen XIN WEN ZHI and the beginning of Lin Zexu's marching toward the modern times (Part I)]. Journal of Sun Yat-sen University. (2):60-67.

CHEN, Xiaoming 陈晓明 (1998): 林则徐译书与《澳门新闻纸》[Lin Zexu'sbook translation and Macau News]. Southeast culture. (4):113-116. 
Chen, Yuan 陈原 (1979): 书林漫步 [Strolls in the book forest]. Beijing: Joint Publishing Company. CHInese History Society 中国史学会 (1954): 中国近代史资料丛刊: 鸦片战争II [Collection of documents of modern history of China: the opium war II]. Shanghai: Shengguang Press.

EAgLeton, Terry (1991/2007): Ideology: An Introduction. London and New York: Verso.

EAgLETON, Terry (1994): Ideology. London and New York: Longman.

FAY, Peter Ward (1997): The Opium War, 1840-1842. North Carolina: University of North Carolina Press.

GAO, Guangjing 高光晶 (1994): 中国封建社会农民起义失败的原因 [Causes of failure of peasant uprisings in feudal China]. Social Science Journal of Hunan Normal University. (5):79-83.

Hatım, Basil and Mason, Ian (1997): The Translator as Communicator. London and New York: Routledge.

HuANG, Lihua 黄利花 (2013): 林则徐外交活动与近代早期外事翻译 [Lin Zexu's diplomatic activities and early diplomatic translation in the modern times]. Lantai world. (8):81-82.

HuANG, Xiaojia and WANG, Yongjian 黄晓佳, 王永健 (2014): 翻译赞助目的研究初探-以林则徐 主政广东的翻译赞助活动为例 (1839-1840) [On the purposes of translation patronage: a case study of the purposes of Lin Zexu as a translation patron during his governance in Canton (1839-1840)]. Journal of Guangdong Polytechnic Normal University (social sciences). (4):80-84.

Hunter, William C. (1885): Bits of Old China. London: Kegan Paul, Trench \& Company.

JIANG, Huimin 江慧敏 (2010): 试论意识形态对翻译的影响——以利玛窦的翻译实践活动为个 案 [On the impact of ideology on translation: a case study of Matteo Ricci's translation activities]. Journal of Yanshan University (philosophy and social science edition). (3):105-108.

Lefevere, Andrew (1992): Translation, Rewriting and the Manipulation of Literary Fame. London and New York: Routledge.

Liv, Lydia H. (1995): Translingual Practice: Literature, National Culture, and Translated Modernity - China, 1900-1937. Stanford: Stanford University Press.

Luo, Bingliang 罗炳良 (2002): 四洲志 [Accounts of four continents]. Beijing: Cathay Press.

MARx, Karl (1995): Preface to the critique of political economy. Selected Works of Marx and Engels. Vol. 2. Beijing: People's Publishing House.

MARX, Karl and Engels, Frederick (1965): The German Ideology. London: Lawrence \&Wishart. McLaren, Peter (1991): Readings. London and New York: Verso.

Nord, Christiane (1997): Translating as a Purposeful Activity: Functionalist Approaches Explained. Manchester: St. Jerome Publishing.

O’Neal, John C. (1996): Authority of Experience: Sensationist Theory in the French Enlightenment. State College: the Pennsylvania State University Press.

SCHAFfNer, Christina (2003): Third ways and new centres: Ideological unity or difference? In: Perez Calzada, eds. A Propos of Ideology: Translation Studies on Ideology - Ideologies in Translation Studies. Manchester: St. Jerome Publishing, 23-42.

SHAO, Xueping and Lin, Benchun 邵雪萍, 林本椿 (2002): 林则徐和他的翻译班子 [Lin Zexu and his translation team]. Shanghai journal of translators for science and technology. (4):47-49.

Sмiтн, Carl T. (1985): Chinese Christians: Elites, Middlemen, and the Church in Hong Kong. Oxford: Oxford University Press.

TANG, Fang 唐昉 (2007): 论翻译发起人的角色——林则徐翻译活动个案研究 [Initiator's role in translation: A case study of Lin Zexu]. Journal of Chongqing University of Arts and Science (Social sciences edition). (2):102-106.

Vattel, Emmerich De. (1844): The Law of Nations, or Principles of the Law of Nature; Applied to the Conduct and Affairs of Nations and Sovereigns (Sixth American Edition). Philadelphia: T. \& J. W. Johnson.

Waley, Arthur (1958): The Opium War Through Chinese Eyes. Stanford: Stanford University Press. WANG, Weijian 王维俭 (1985): 林则徐翻译西方国际法著作考略 [An investigation of Lin Zexu's translation of western international law books]. Journal of Sun Yat-sen University. (1):58-67.

WEI, Yuan 魏源 (1852): 夷情备采 [A collection of foreign affairs]. 海国图志 [An illustrated gazette of maritime countries]. Vol. 81. 
WEI, Yuan 魏源 (1976): 道光洋艘征抚记 (卷上) [Records of subjugation of foreign warships in the reign of Daoguang (Part I)]. 魏源集 (上册) [Works of Wei Yuan (Book I)]. Beijing: Zhonghua Book Company.

WEN, Qing 文庆 (1964): 筹办夷务始末.道光朝 [History of diplomatic affairs in late Qing Dynasty, reign of Daoguang]. Beijing: Zhonghua Book Company.

Wu, Qiandui and Chen, Kuangshi 吴乾兑, 陈匡时 (1980): 林译《澳门月报》及其它 [Lin Zexu’s translation of Aomen Yuebao and beyond]. Modern Chinese history studies. (3):264-277.

XIAO, Zhizhi 萧致治 (1999): 从 《四洲志》的编译看林则徐眼中的世界 [The world in Lin Zexu's eyes seen from his trans-editing of Si Zhou Zhi]. Fujian tribune (The humanities \& social sciences monthly). (4):51-55.

YANG, Guozhen 杨国桢 (1981): 林则徐传 [Biography of Lin Zexu]. Beijing: People Press.

ZHENG, Liangen 郑连根 (2004): 林则徐译报: 中国人办报的先声 [Lin Zexu's newspaper translation: Herald of China's newspaper running]. Yanhuangchunqiu. (7):78-79. 